\title{
Metabolic Control Mechanisms in Mammalian Systems
}

\author{
INVOLVEMENT OF ADENOSINE $3^{\prime}: 5^{\prime}$-CYCLIC MONOPHOSPHATE IN ANDROGEN ACTION
}

\author{
BY RADHEY L. SINGHAL, M. R. PARULEKAR AND R. VIJAYVARGIYA \\ Department of Pharmacology, University of Ottawa, Faculty of Medicine, Ottawa 2, Ont., Canada \\ AND G. ALAN ROBISON \\ Department of Pharmacology, Vanderbilt University, Nashville, Tenn., U.S.A.
}

(Received 11 January 1971)

\begin{abstract}
1. The ability of exogenously administered cyclic AMP (adenosine $3^{\prime}: 5^{\prime}$-monophosphate) to exert andromimetic action on certain carbohydrate-metabolizing enzymes was investigated in the rat prostate gland and seminal vesicles. 2. Cyclic AMP, when injected concurrently with theophylline, produced marked increases in hexokinase, phosphofructokinase, glyceraldehyde phosphate dehydrogenase, pyruvate kinase, and two hexose monophosphate-shunt enzymes, as well as $\alpha$-glycerophosphate dehydrogenase activity in accessory sexual tissues of castrated rats. The 6-N,2'-O-dibutyryl analogue of cyclic AMP caused increases of enzyme activity that were greater than those induced by the parent compound. 3. Timecourse studies demonstrated that, whereas significant increases in the activities of most enzymes occurred within $4 \mathrm{~h}$ after the injection of cyclic AMP, maximal increases were attained at 16-24h. 4. Increase in the activity of the various prostatic and vesicular enzymes was dependent on the dose of cyclic AMP; in most instances, $2.5 \mathrm{mg}$ of the cyclic nucleotide/rat was sufficient to elicit a statistically significant response. 5. Administration of cyclic AMP and theophylline also produced stimulation of enzyme activities in secondary sexual tissues of immature rats. 6. Cyclic AMP and theophylline did not affect significantly any of the enzymes studied in hepatic tissue. 7. Stimulation of various carbohydrate-metabolizing enzymes in the prostate gland and seminal vesicles by cyclic AMP was independent of adrenal function. 8. Concurrent treatment with actinomycin or cycloheximide prevented the cyclic AMP- and theophylline-induced increases in enzyme activities in both castrated and adrenalectomized-castrated animals. 9. Administration of a single dose of testosterone propionate $(5.0 \mathrm{mg} / 100 \mathrm{~g})$ to castrated rats caused a significant increase in cyclic AMP concentration in both accessory sexual tissues. 10. In addition, treatment with theophylline potentiated the effects of a submaximal dose of testosterone $(1.0 \mathrm{mg} / 100 \mathrm{~g})$ on all those prostatic and seminalvesicular enzymes that are increased by exogenous cyclic AMP. 11. The evidence indicates that cyclic AMP may be involved in triggering the known metabolic actions of androgens on secondary sexual tissues of the rat.
\end{abstract}

The multiplicity of levels at which hormones act on biological systems makes them versatile tools for elucidating the regulatory mechanisms involved in the maintenance of homeostasis. Studies of the mechanisms that control metabolic processes in accessory sexual tissues demonstrated that sex hormones are capable of inducing the synthesis of several important enzymes involved in carbohydrate metabolism (Singhal, Valadares \& Ling, 1967; Singhal, Wang \& Ling, 1968; Valadares, Singhal \& Parulekar, 1968; Singhal \& Valadares, 1968; Singhal, Valadares \& Ling, 1969; Singhal \& Ling, 1969; Vijayvargiya, Schwark \& Singhal,
1969; Singhal \& Valadares, 1970). The activity of prostatic and vesicular hexokinase, phosphofructokinase and glucose 6-phosphate dehydrogenase markedly declined on castration; these effects of castration were reversed by the administration of testosterone (Singhal \& Valadares, 1968; Singhal et al. 1968; Singhal \& Ling, 1969). Stimulation of prostatic and seminal-vesicular enzymes by testosterone was inhibited by several compounds known to inhibit synthesis of RNA and protein, suggesting that the testosterone-induced increases in various enzymes may represent enzyme synthesis de novo and that stimulation of the synthesis of 
certain RNA species may be a primary response to androgenic stimulation. The observed increases in prostatic and vesicular enzymes also were inhibited by the administration of oestradiol-17 $\beta$ to testosterone-treated rats, although this oestrogen by itself exerted no significant effect (Singhal \& Valadares, 1968; Singhal \& Ling, 1969).

Androgens affect a variety of important metabolic processes in the prostate gland and seminal vesicles (Williams-Ashman, 1965a,b; Singhal \& Valadares, 1968; Singhal \& Ling, 1969); however, our knowledge of the mechanism(s) that trigger the action of these hormones on the target cells is lacking. Since cyclic AMP is known to act as an intracellular mediator in the mechanism of action of epinephrine and glucagon, several hormones and biogenic amines are now believed to act via the agency of this cyclic nucleotide (Butcher, Robison, Hardman \& Sutherland, 1968b; Sutherland, Robison \& Butcher, 1968; Sutherland \& Robinson, 1969; Sutherland, Hardman, Butcher \& Broadus, 1969; Robison, 1970). To our knowledge, cyclic AMP has never been implicated in the mechanism of action of androgens, although recent work indicates that this nucleotide may be involved in mediating the action of oestrogens on the uterus (Szego \& Davis, 1967; Hechter, Yoshinaga, Halkerstan \& Birchall, 1967; Singhal \& Lafreniere, 1970). To see if cyclic AMP is concerned with the propagation of various enzymic responses induced by androgens, the ability of exogenously administered cyclic AMP to produce testosterone-like induction of several prostatic and vesicular enzymes was investigated. Preliminary accounts of parts of this work have appeared (Singhal, Vijayvargiya \& Ling, 1970b; Singhal, Vijayvargiya, Parulekar \& Ling, 1970c; Singhal, Robison \& Parulekar, 1971).

\section{MATERIALS AND METHODS}

Animals. Experiments were carried out on adult castrated rats of the Wistar strain weighing approx. $150 \mathrm{~g}$ at the time of surgery. The animals were castrated bilaterally via the scrotal route under light pentobarbital anaesthesia and used only after a post-operative period of 2 weeks had elapsed. Some castrated rats also were adrenalectomized and given post-operative care as described by Singhal \& Valadares (1967) and Singhal \& Lafreniere (1970).

Chemicals and doses. All reagents were of the purest grade available. Testosterone propionate, from Sigma Chemical Co., St Louis, Mo., U.S.A., was dissolved in ethanolic $0.9 \% \mathrm{NaCl}$ and injected intramuscularly, in a single dose of $1.0,5.0$ or $10.0 \mathrm{mg} / 100 \mathrm{~g}$ body wt. Cyclic AMP, from Calbiochem, Los Angeles, Calif., U.S.A., was dissolved in $0.9 \% \mathrm{NaCl}$, adjusted to $\mathrm{pH} 7.4$ by adding $2 \% \mathrm{Na}_{2} \mathrm{CO}_{3}$ and injected intraperitoneally, at a dose of $10.0 \mathrm{mg} / \mathrm{rat}$ in two equally divided doses at $12 \mathrm{~h}$ intervals. Theophylline (10.0 mg/rat), also dissolved in $0.9 \% \mathrm{NaCl}$, was given by the intraperitoneal route in two equal doses concurrently with cyclic AMP. 6- $N, 2^{\prime}$-O-Dibutyryl cyclio AMP (kindly given by Dr Nelboeic of C.F. Boehringer und Soehne G.m.b.H., Mannheim, Germany) was injected intraperitoneally, in two equally divided doses at $12 \mathrm{~h}$ intervals. Control animals received an equal volume of $0.9 \% \mathrm{NaCl}$. Actinomycin D $(25.0 \mu \mathrm{g} / 100 \mathrm{~g})$ or cycloheximide $(70.0 \mu \mathrm{g} / 100 \mathrm{~g})$ were dissolved in $0.9 \% \mathrm{NaCl}$ and injected intraperitoneally, concurrently with testosterone or cyclic AMP. All other biochemicals and intermediates used in the assay of various enzymes were purchased from Sigma Chemical Co.

Preparation of supernatant fluids and enzyme assays. The rats were stunned, decapitated and bled. The prostate glands and seminal vesicles were excised quickly, cleaned of all extraneous tissue and their fluid content was extruded under light pressure (Singhal \& Valadares, 1968). Prostate glands and seminal vesicles from several animals were pooled and finely minced with scissors. The minced tissue was homogenized in iso-osmotic $\mathrm{KCl}$, $\mathrm{pH} \mathrm{7.4,} \mathrm{and} 5 \%(w / v)$ homogenates and supernatant fluids were prepared (Singhal et al. 1967; Singhal \& Valadares, 1968). The activities of hexokinase (Valadares et al. 1968; Singhal \& Ling, 1969), phosphofructokinase (Singhal et al. 1967; Singhal \& Valadares, 1968), pyruvate kinase (Vijayvargiya et al. 1969; Singhal \& Valadares, 1970), glucose 6-phosphate dehydrogenase (Singhal, Valadares \& Schwark, 1970a), 6-phosphogluconate dehydrogenase (Singhal et al. 1970a) and $\alpha$-glycerophosphate dehydrogenase (Vijayvargiya \& Singhal, 1970) were assayed in the supernatant fluid. Glyceraldehyde phosphate dehydrogenase activity was also measured in the supernatant fluid according to the procedure of Freedland (1969). Cyclic AMP in purified tissue extracts was measured by the method based on the activation of liver phosphorylase (Butcher, Ho, Meng \& Sutherland, 1965) and expressed in terms of pmol per total prostate or seminal vesicles. All enzyme activities were assayed under strictly linear kinetic conditions and expressed as ( $\mu \mathrm{mol}$ of substrate metabolized/h per $\mathrm{g}$ of tissue) $\times$ the organ weight as described earlier (Singhal et al. 1967; Singhal \& Valadares, 1968; Singhal \& Ling, 1969). The results were subjected to statistical evaluation and significant differences between the means (calculated as $P$ values) are shown. No statistical significance is indicated when the $P$ value was $>0.05$.

\section{RESULTS}

Effect of cyclic AMP, $5^{\prime}$-AMP and theophylline. The results presented in Tables 1 and 2 show that $5^{\prime}$-AMP, when given to castrated rats, exerted no significant effect on either the organ weights or any of the prostatic and vesicular enzymes investigated. Cyclic AMP alone resulted only in minor increases, but marked enhancement of enzyme activities was produced when the cyclic nucleotide was injected with theophylline, an inhibitor of the phosphodiesterase that inactivates cyclic AMP. Theophylline alone also produced small, yet statistically significant, stimulation of most of the prostatic and vesicular enzymes studied. When the 6- $N, 2^{\prime}-O$. dibutyryl analogue of cyclic AMP was injected 


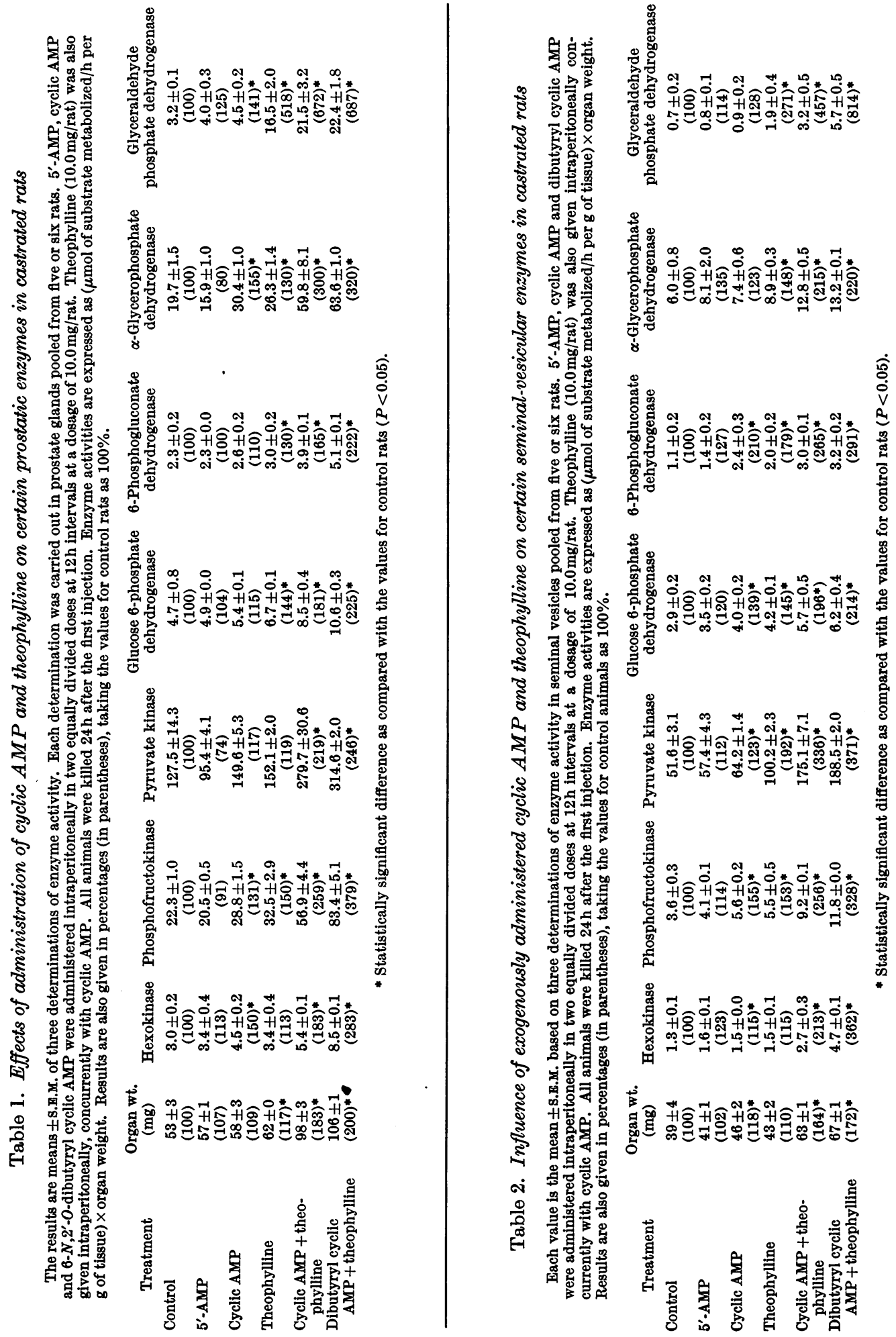


with theophylline, it produced increases in prostate and seminal-vesicle weights as well as enzyme activities that were greater than those observed with cyclic AMP and theophylline. Similar increases in the activities of various enzymes were noted for seminal vesicles with glyceraldehyde phosphate dehydrogenase being the most responsive (814\%) among all the enzymes investigated.

Effect of chronic cyclic $A M P$ treatment. Since treatment with cyclic AMP and theophylline during $24 \mathrm{~h}$ resulted in significant increases in enzyme activities, the possibility that the prostate gland and seminal vesicles, when stimulated chronically by cyclic AMP, might show more pronounced increases was investigated. Accordingly, castrated rats were injected with cyclic AMP $(5.0 \mathrm{mg} / \mathrm{rat})$ and theophylline $(10.0 \mathrm{mg} / \mathrm{rat})$ in two divided doses at $12 \mathrm{~h}$ intervals daily for 3 days and killed $72 \mathrm{~h}$ after the beginning of this treatment. The results presented in Fig. 1 demonstrate that significant increases in glycolytic and hexose monophosphateshunt enzymes as well as in the activity of $\alpha$ glycerophosphate dehydrogenase were produced in both accessory sex organs. However, this treatment generally failed to produce any greater increases in prostatic and vesicular enzymes than those observed during $24 \mathrm{~h}$ after the injection of $10.0 \mathrm{mg}$ each of cyclic AMP and theophylline.

Time-course of cyclic AMP-induced changes. To follow the time-course of cyclic AMP-stimulated changes in prostatic and vesicular enzymes, sequen- tial changes were studied for a period of $24 \mathrm{~h}$ after administration of cyclic AMP and theophylline. Whereas prostate weights increased respectively to $135 \%, 140 \%, 166 \%$ and $183 \%$, vesicular weights were 103, 123, 141 and $164 \%$ of the control values at 4, 8, 16 and $24 \mathrm{~h}$ after the injection of cyclic AMP and theophylline. Fig. 2 shows that detectable increases in all prostatic enzymes examined could be observed at $4 \mathrm{~h}$. Enzyme activities increased progressively during the $16 \mathrm{~h}$ period, at which time peak increases were noted for hexokinase, glucose 6-phosphate dehydrogenase, 6 phosphogluconate dehydrogenase and glyceraldehyde phosphate dehydrogenase. In contrast, maximal enhancement of prostatic phosphofructokinase, pyruvate kinase and $\alpha$-glycerophosphate dehydrogenase was observed $24 \mathrm{~h}$ after the administration of cyclic AMP and theophylline.

Fig. 3 shows that statistically significant increases in all seminal-vesicular enzymes, excepting the two hexose monophosphate-shunt dehydrogenases, were also produced at $4 \mathrm{~h}$. The peak response of vesicular hexokinase $(264 \%)$ and glyceraldehyde phosphate dehydrogenase $(743 \%)$ was noted at $16 \mathrm{~h}$, whereas phosphofructokinase $(256 \%)$, pyruvate kinase $(336 \%)$, glucose 6-phosphate dehydrogenase $(196 \%), 6$-phosphogluconate dehydrogenase $(265 \%)$ and $\alpha$-glycerophosphate dehydrogenase (215\%) exhibited maximal increases $24 \mathrm{~h}$ after treatment with cyclic AMP and theophylline.

Dose-response studies with cyclic $A M P$. The re-

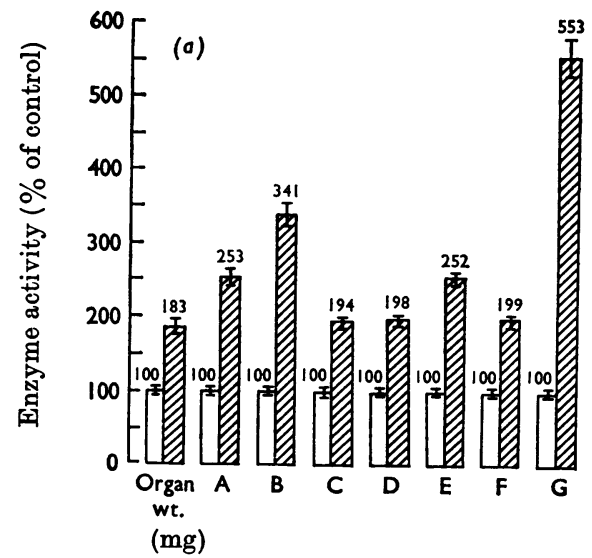

(b)

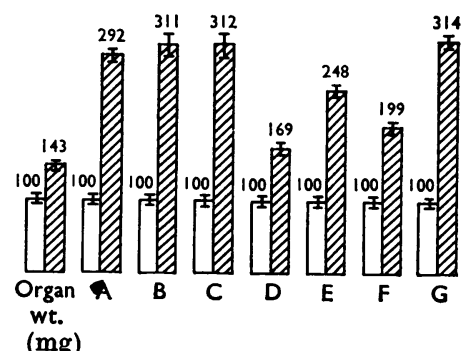

Fig. 1. Effect of chronic cyclic AMP and theophylline treatment on certain $(a)$ prostatic and (b) seminalvesicular enzymes. Bars represent the means and s.E.M. of three values each obtained by pooling prostate glands and seminal vesicles from four or five rats. Cyclic AMP $(5.0 \mathrm{mg} / \mathrm{rat})$ and theophylline $(10.0 \mathrm{mg} / \mathrm{rat})$ were injected concurrently, by the intraperitoneal route, in two equally divided doses at $12 \mathrm{~h}$ intervals daily for 3 days, and the rats were killed $72 \mathrm{~h}$ after treatment was begun. Results are given in percentages, taking the values for control rats as $100 \%$. A, Hexokinase; B, phosphofructokinase; C, pyrurate kinase; D, glucose 6-phosphate dehydrogenase; E, 6-phosphogluconate dehydrogenase; F, $\alpha$-glycerophosphate dehydrogenase; G, glyceraldehyde phosphate dehydrogenase. $\square$, Control; $\mathbb{2}$, cyclic AMP + theophylline. All experimental values were significantly different when compared with the values for control rats $(P<0.05)$. 


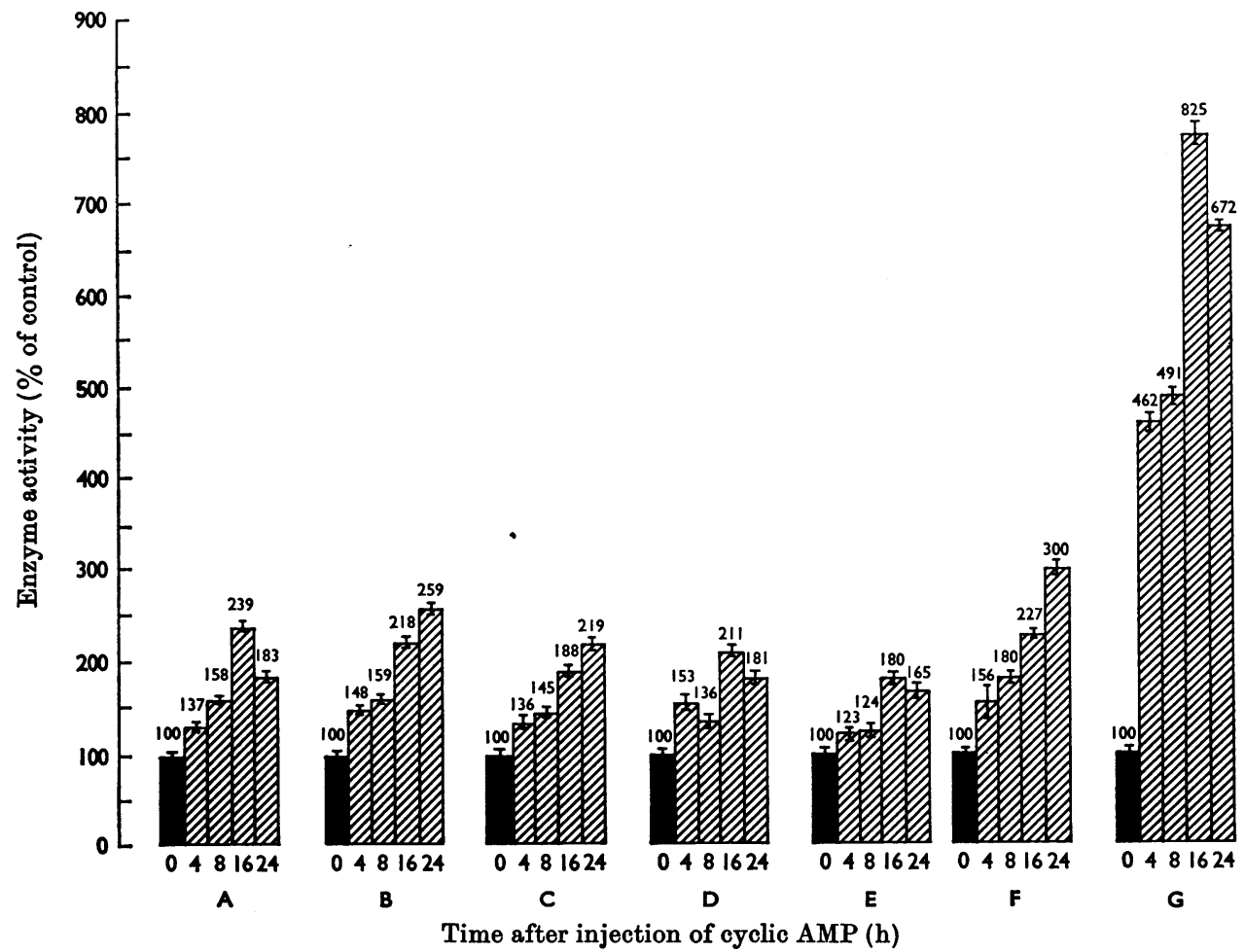

Fig. 2. Time-course of cyclic AMP- and theophylline-induced changes in prostatic enzymes. Bars represent the means and s.E.M. of three values each obtained by pooling prostate glands from four or five rats. Cyclic AMP $(10.0 \mathrm{mg} / \mathrm{rat})$ and theophylline $(10.0 \mathrm{mg} / \mathrm{rat})$ were injected intraperitoneally in two equally divided doses and the rats were killed after 4, 8, 16 and $24 \mathrm{~h}$. A, Hexokinase; B, phosphofructokinase; C, pyruvate kinase; D, glucose 6-phosphate dehydrogenase; E, 6-phosphogluconate dehydrogenase; F, $\alpha$-glycerophosphate dehydrogenase; G, glyceraldehyde phosphate dehydrogenase. Results are given in percentages, taking the values for control animals as $100 \%$, and are statistically significantly different when compared with the values for control rats $(P<0.05)$. $\square$, Control;, , cyclic AMP + theophylline.

sults in Tables 3 and 4 show that the observed cyclic AMP-induced changes in various prostatic and vesicular enzymes were related to the dose of the cyclic nucleotide. A dose of $2.5 \mathrm{mg} / \mathrm{rat}$ was sufficient to induce a statistically significant increase in the activity of most enzymes. Increasing the dose of cyclic AMP to $5.0,10.0$ and $20.0 \mathrm{mg} / \mathrm{rat}$ resulted in further enhancement of various prostatic and vesicular enzymes with maximal increases being obtained with the $20.0 \mathrm{mg}$ dose.

Influence of cyclic $A M P$ on immature rats. The results in Table 5 show that the administration of cyclic AMP and theophylline to immature animals produced increases in prostate-gland and seminalvesicle weights as well as carbohydrate-metabolizingenzymeactivities that were similar to those observed for castrated rats.

Influence of actinomycin and cycloheximide. The androgenic induction of prostatic and vesicular hexokinase, phosphofructokinase and glucose 6phosphate dehydrogenase may involve enzyme synthesis, since the hormone-stimulated increases in their activities are blocked by a variety of compounds known to inhibit the synthesis of RNA and proteins (Singhal \& Valadares, 1968; Singhal \& Ling, 1969). Fig. 4 shows that actinomycin, which binds to DNA and blocks DNA-directed synthesis of nuclear RNA (Reich, Franklin, Shatkin \& Tatum, 1961 ; Tamaoki \& Mueller, 1962), also inhibited the testosterone-stimulated increases in the activities of pyruvate kinase, 6-phosphogluconate dehydrogenase, $\alpha$-glycerophosphate dehydrogenase and glyceraldehyde phosphate dehydrogenase in both prostate and seminal vesicles. Cycloheximide, which interferes with protein synthesis by blocking the transfer of amino acids from tRNA to protein (Ennis \& Lubin, 1964; Siegel \& Sisler, 1964), also prevented the steroid-induced increases in prostatic 


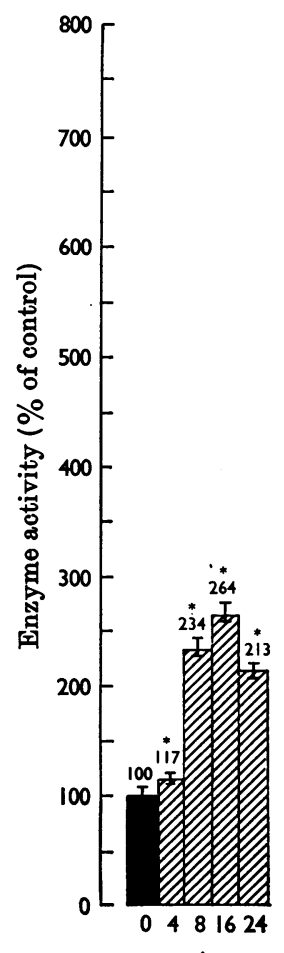

A

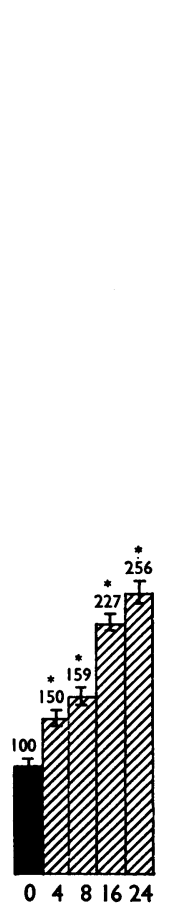

B

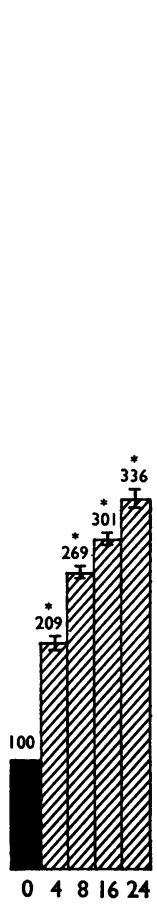

c

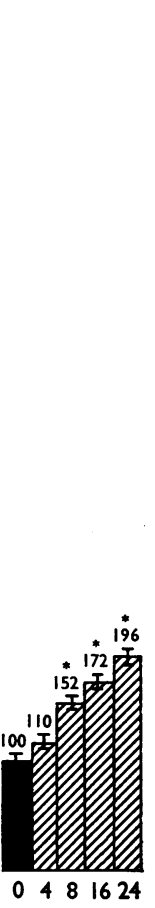

D

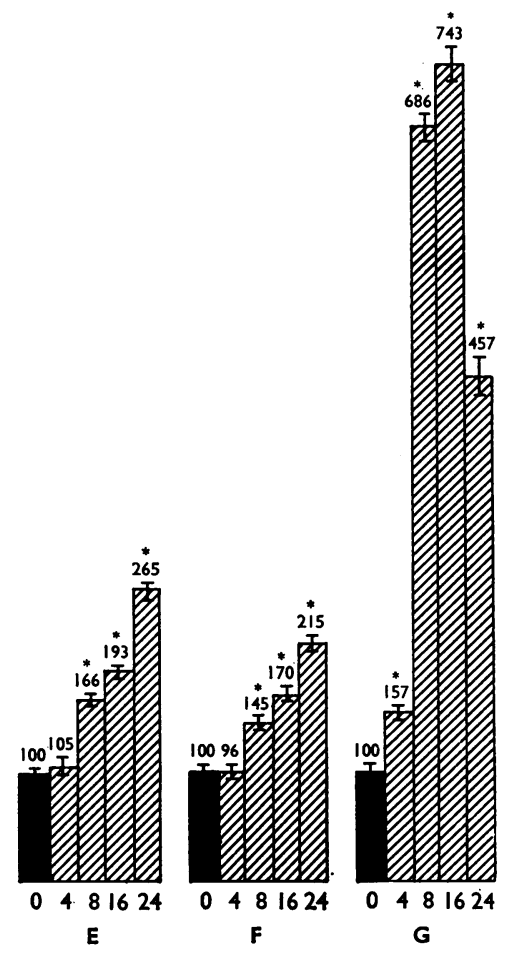

Time after injection of cyclic AMP (h)

Fig. 3. Time-course of cyclic AMP- and theophylline-induced changes in seminal-vesicular enzymes. Bars represent the means and S.E.M. of three values each obtained by pooling seminal vesicles from four or five rats. Cyclic AMP $(10.0 \mathrm{mg} / \mathrm{rat})$ and theophylline $(10.0 \mathrm{mg} / \mathrm{rat})$ were injected intraperitoneally in two equally divided doses and the rats were killed after 4, 8, 16 and $24 \mathrm{~h}$. A, Hexokinase; B, phosphofructokinase; C, pyruvate kinase; D, glucose 6-phosphate dehydrogenase; E, 6-phosphogluconate dehydrogenase; F, $\alpha$-glycerophosphate dehydrogenase; G, glyceraldehyde phosphate dehydrogenase. Results are given in percentages, taking the values for control animals as $100 \%$. E, Control; 1 , cyclic AMP + theophylline. *Statistically significant difference as compared with the values for control rats $(P<0.05)$.

and vesicular pyruvate kinase, $\alpha$-glycerophosphate dehydrogenase and glyceraldehyde phosphate dehydrogenase as well as the hexose monophosphateshunt enzyme.

Since actinomycin and cycloheximide are capable of blocking the testosterone-induced enzymic responses in the prostate and seminal vesicles, the effect of these inhibitors was examined on the cyclic AMP-stimulated increases in various enzyme activities. Results in Fig. 5 and Table 6 show that concurrent treatment of cyclic AMP-injected rats with actinomycin or cycloheximide interfered with the cyclic nucleotide-induced rise in the activities of various prostatic and vesicular enzymes. Enhancement of the prostatic and vesicular weights induced by cyclic AMP and theophylline also was prevented by the two inhibitors of RNA and protein synthesis.

Influence of cyclic AMP in adrenalectomizedcastrated rats. To see if the adrenal glands are involved in the observed stimulation of prostatic and vesicular enzymes, the effect of cyclic AMP and theophylline on adrenalectomized-castrated rats was investigated. This treatment enhanced prostatic and vesicular weights to $187 \%$ and $166 \%$ of the control values, respectively. Fig. 6 shows that when cyclic AMP and theophylline were administered concurrently to adrenalectomized-castrated rats, the activities of all prostatic and vesicular enzymes examined increased generally to about the same extent as that observed in castrated rats. A notable exception was glyceraldehyde phosphate dehydrogenase activity, which did not increase as markedly as in castrated rats with intact adrenals. Fig. 6 also shows that when cyclic AMP - and theophyllinetreated adrenalectomized-castrated rats were given either actinomycin or cycloheximide, the observed increases in prostatic and vesicular enzyme activities were inhibited and the values remained near those of the controls. The results suggest that 

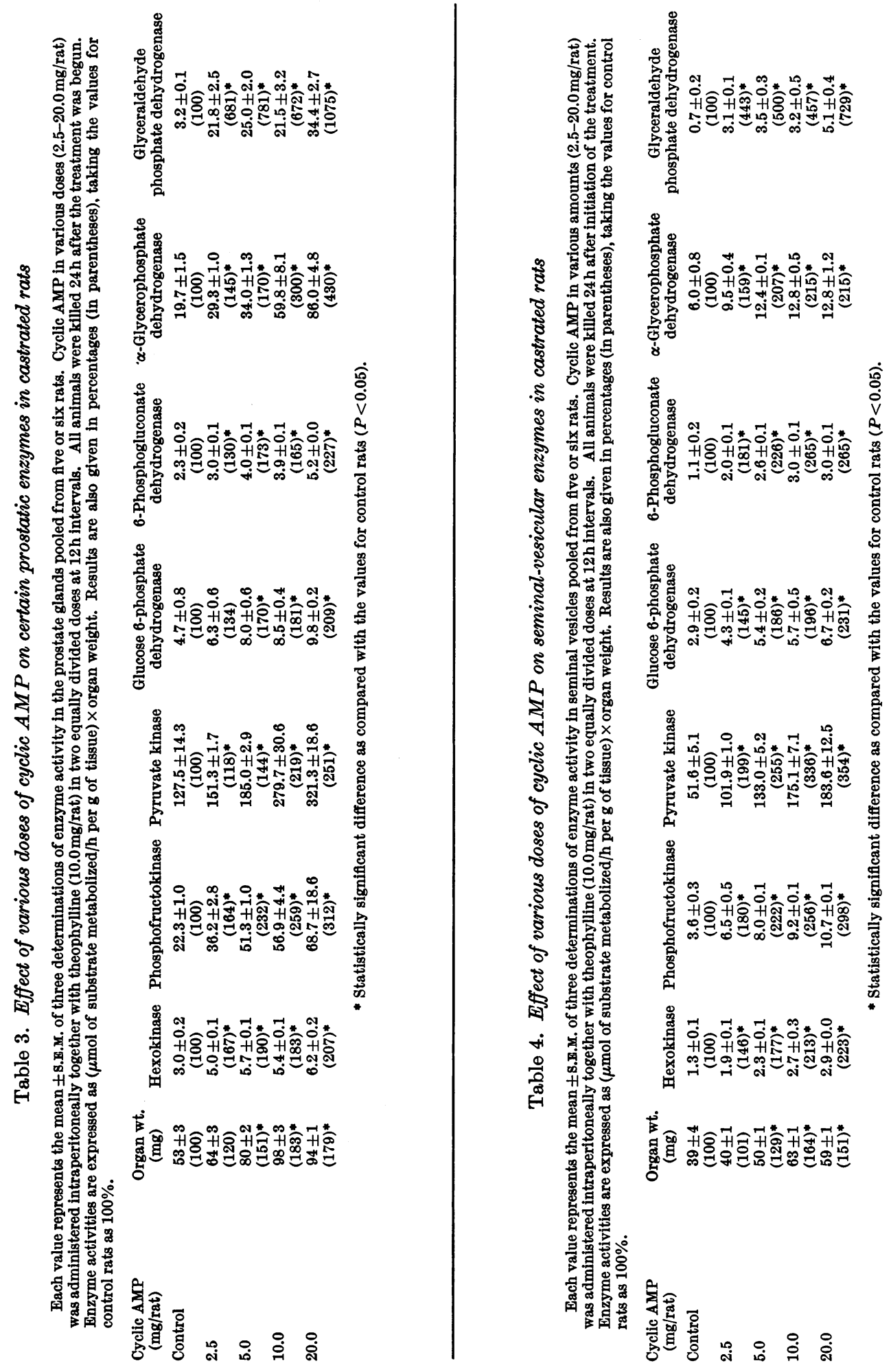
Table 5. Stimulation of carbohydrate-metabolizing enzymes by cyclic AMP in the prostate and seminal vesicles of immature rats

The results represent means \pm S.E.M. of three determinations of enzyme activity. Each determination was carried out in the prostate glands and seminal vesicles pooled from five or six immature rats. Cyclic AMP $(10.0 \mathrm{mg} / \mathrm{rat})$ and theophylline $(10.0 \mathrm{mg} / \mathrm{rat})$ were administered concurrently by the intraperitonea] route in two equally divided doses at $12 \mathrm{~h}$ intervals. Animals were killed $24 \mathrm{~h}$ after the initiation of the treatment. Enzyme activities are expressed as ( $\mu \mathrm{mol}$ of substrate metabolized/h per $\mathrm{g}$ of tissue) $\times$ organ weight. The results are also given in percentages (in parentheses), taking the values for control rats as $100 \%$.

\begin{tabular}{|c|c|c|}
\hline \multirow[b]{2}{*}{ Enzymo } & \multicolumn{2}{|r|}{ Prostate } \\
\hline & Control & Cyclic AMP + theophylline \\
\hline Organ wt. (mg) $\quad \ldots$ & $\begin{array}{l}46 \pm 4 \\
(100)\end{array}$ & $\begin{array}{l}77 \pm 4 \\
(168)^{*}\end{array}$ \\
\hline Hexokinase & $\begin{array}{l}3.1 \pm 0.1 \\
(100)\end{array}$ & $\begin{array}{l}6.3 \pm 0.1 \\
(203)^{*}\end{array}$ \\
\hline Phosphofructokinase & $\begin{array}{c}7.6 \pm 0.5 \\
(100)\end{array}$ & $\begin{array}{c}21.2 \pm 0.3 \\
(280)^{*}\end{array}$ \\
\hline Pyruvate kinase & $\begin{array}{l}80.0 \pm 0.7 \\
(100)\end{array}$ & $\begin{array}{c}227.0 \pm 7.6 \\
(284)^{*}\end{array}$ \\
\hline $\begin{array}{l}\text { Glucose 6-phosphate } \\
\text { dehydrogenase }\end{array}$ & $\begin{array}{l}4.0 \pm 0.3 \\
(100)\end{array}$ & $\begin{array}{l}7.0 \pm 0.1 \\
(175)^{*}\end{array}$ \\
\hline $\begin{array}{l}\text { 6-Phosphogluconate } \\
\text { dehydrogenase }\end{array}$ & $\begin{array}{l}1.4 \pm 0.1 \\
(100)\end{array}$ & $\begin{array}{l}2.4 \pm 0.1 \\
(170)^{*}\end{array}$ \\
\hline $\begin{array}{l}\alpha \text {-Glycerophosphate } \\
\text { dehydrogenase }\end{array}$ & $\begin{array}{l}15.6 \pm 0.8 \\
(100)\end{array}$ & $\begin{array}{l}49.6 \pm 3.9 \\
(317)^{*}\end{array}$ \\
\hline $\begin{array}{l}\text { Glyceraldehyde phos- } \\
\text { phate dehydrogenase }\end{array}$ & $\begin{array}{l}2.7 \pm 0.2 \\
(100)\end{array}$ & $\begin{array}{c}12.8 \pm 2.0 \\
(473)^{*}\end{array}$ \\
\hline
\end{tabular}

\begin{tabular}{cc}
\multicolumn{2}{c}{ Seminal vesicles } \\
$\overbrace{\text { Control }}$ & Cyclic AMP + theophylline \\
$14 \pm 1$ & $20 \pm 1$ \\
$(100)$ & $(143)^{*}$ \\
$0.8 \pm 0.1$ & $1.4 \pm 0.1$ \\
$(100)$ & $(175)^{*}$ \\
$1.3 \pm 0.1$ & $3.4 \pm 0.1$ \\
$(100)$ & $(261)$ \\
$27.2 \pm 2.1$ & $46.9 \pm 0.1$ \\
$(100)$ & $(174)^{*}$ \\
$0.8 \pm 0.0$ & $1.6 \pm 0.1$ \\
$(100)$ & $(200)^{*}$ \\
$0.4 \pm 0.0$ & $0.6 \pm 0.0$ \\
$(100)$ & $(150)^{*}$ \\
$3.4 \pm 0.4$ & $8.1 \pm 1.0$ \\
$(100)$ & $(239)^{*}$ \\
$0.3 \pm 0.0$ & $1.3 \pm 0.1$ \\
$(100)$ & $(433)^{*}$
\end{tabular}

* Statistically significant difference as compared with the values for control rats $(P<0.05)$.
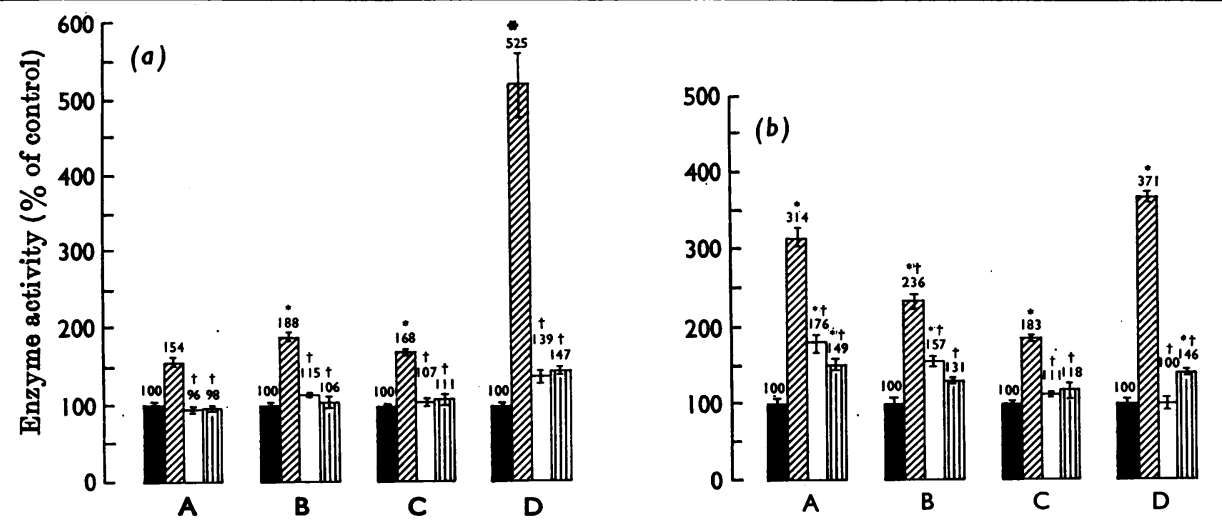

Fig. 4. Effect of actinomycin and cycloheximide on testosterone-induced increases in the activities of pyruvate kinase (A), 6-phosphogluconate dehydrogenase (B), $\alpha$-glycerophosphate dehydrogenase (C) and glyceraldehyde phosphate dehydrogenase $(D)$ in $(a)$ the prostate and $(b)$ seminal vesicles. Bars represent the means and s.e.M. of three values each obtained by pooling prostate glands and seminal vesicles from four rats. Castrated rats were injected with testosterone propionate $(5.0 \mathrm{mg} / 100 \mathrm{~g})$ intramuscularly and killed after $24 \mathrm{~h}$. Actinomycin $(25.0 \mu \mathrm{g} / 100 \mathrm{~g})$ or cycloheximide $(70.0 \mu \mathrm{g} / 100 \mathrm{~g})$ was injected intraperitoneally; at the same time testosterone was administered. The results are given in percentages, taking the values for control rats as $100 \%$. $\square$, Control; $\mathbf{0}$, testosterone propionate; $\square$, testosterone propionate+ actinomycin; 四, testosterone propionate+cycloheximide. *Statistically significant difference when compared with the values for control rats $(P<0.05)$. TStatistically significant difference when compared with the values for testosterone-treated rats without actinomycin or cycloheximide administration $(P<0.05)$.

neither the cyclic AMP-induced stimulation of various enzyme activities in the prostate and seminal vesicles nor the inhibition of these re- sponses by actinomycin or cycloheximide is dependent on adrenal function.

Influence of testosterone treatment on cyclic $A M P$ 

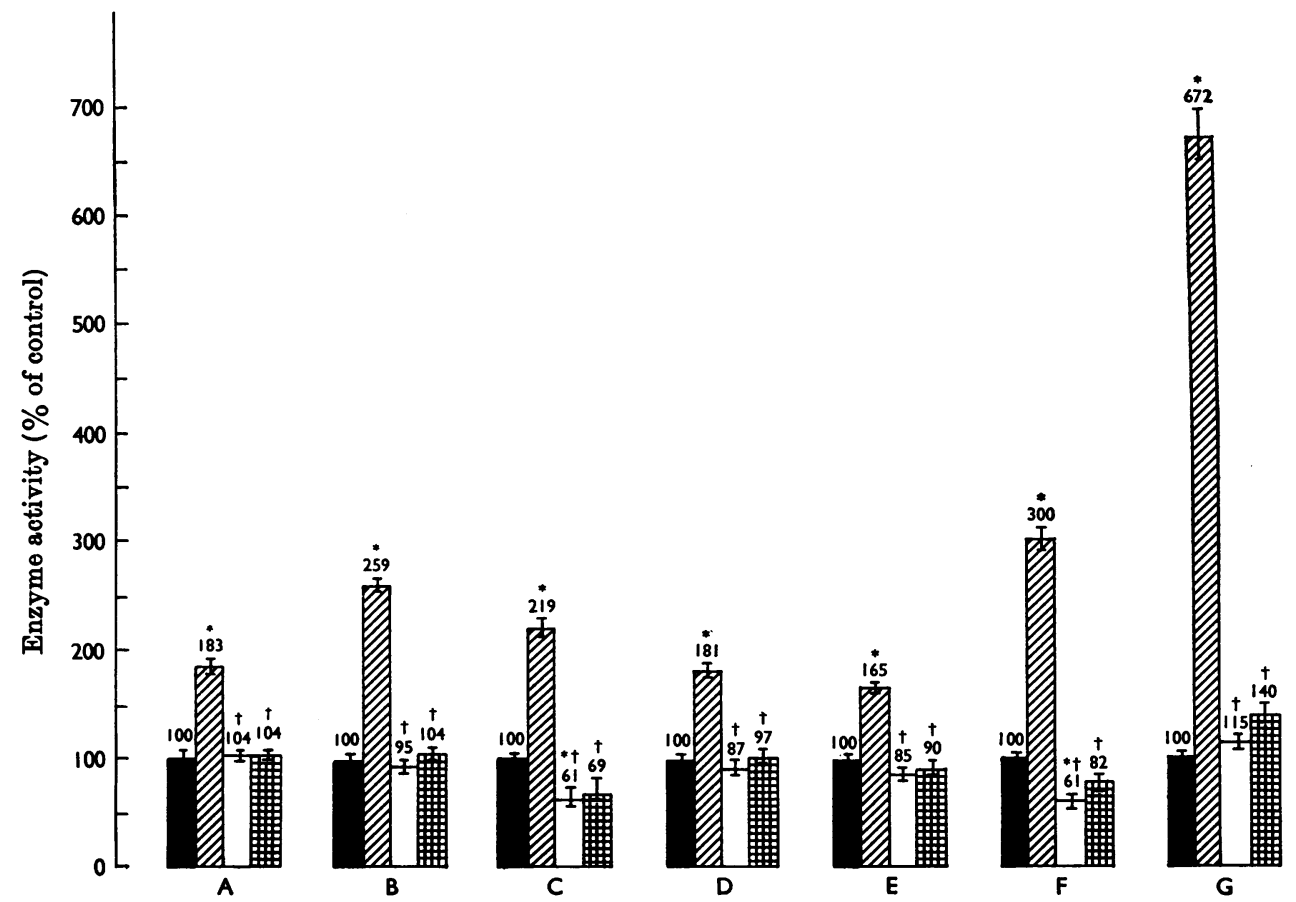

Fig. 5. Effect of actinomycin and cycloheximide on the cyclio AMP-induced increases in prostatic enzymes. Bars represent the means and s.E.M. of three values each obtained by pooling prostate glands from four rats. Cyolic AMP $(10.0 \mathrm{mg} / \mathrm{rat})$ and theophylline $(10.0 \mathrm{mg} / \mathrm{rat})$ were injected intraperitoneally, in two divided doses at $21 \mathrm{~h}$ intervals. Actinomycin $(25.0 \mu \mathrm{g} / 100 \mathrm{~g})$ or cycloheximide $(70.0 \mu \mathrm{g} / 100 \mathrm{~g})$ were also administered by the intraperitoneal route in two equal doses concurrently with cyclic AMP. All animals were killed $24 \mathrm{~h}$ after treatment was begun. A, Hexokinase; B, phosphofructokinase; C, pyruvate kinase; D, glucose 6-phosphate dehydrogenase; E, 6-phosphogluconate dehydrogenase; F, $\alpha$-glycerophosphate dehydrogenase; $G$, glyceraldehyde phosphate dehydrogenase. Results are given in percentages, taking the values for control rats as $100 \%$. $\square$, Control; $\square$, cyclio AMP + theophylline; $\square$, cyclic AMP+theophylline+actinomycin; 睛, cyclic AMP+theophylline+ cycloheximide. * Statistically significant difference when compared with the values for control rats $(P<0.05)$. + Statistically significant difference when compared with the values for rats receiving cyclic AMP and theophylline $(P<0.05)$.

concentration. Groups of rats were treated with testosterone propionate at a dose of $5.0 \mathrm{mg} / 100 \mathrm{~g}$ intramuscularly, and killed after 8 or $24 \mathrm{~h}$. The results in Table 7 show that after a single injection of testosterone, cyclic AMP concentration increased at 8 and $24 \mathrm{~h}$ to 140 and $145 \%$ in the prostate gland and 140 and $210 \%$ of controls (castrated animals) in seminal vesicles, respectively.

Theophylline-induced potentiation of testosterone action. If cyclic AMP mediates the metabolic effects of androgens on the target organs, theophylline would be expected to enhance the influence of a small dose of testosterone on prostatic and vesicular enzymes. The results presented in Tables 8 and 9 show the ability of theophylline to potentiate the action of a submaximal dose of testosterone propionate on various prostatic and vesicular enzymes in castrated rats. Administration of testosterone $(1.0 \mathrm{mg} / 100 \mathrm{~g})$ produced small yet statistically significant increases in organ weights as well as in the activities of all enzymes examined, except in the case of vesicular $\alpha$-glycerophosphate dehydrogenase. However, when the same dose of the hormone was injected concurrently with theophylline, the increases observed in various prostatic and seminal-vesicular enzymes were much greater and were comparable with those observed with the high dose of testosterone $(10.0 \mathrm{mg} / 100 \mathrm{~g})$. The results indicate that when a submaximal dose of testosterone $(1.0 \mathrm{mg} / 100 \mathrm{~g})$ is administered along with an inhibitor of phosphodiesterase, the increases produced in various enzymes are similar to those observed with the $10.0 \mathrm{mg} / 100 \mathrm{~g}$ dose of the hormone.

\section{DISCUSSION}

Of the hormones that are thought to act through the agency of cyclic AMP, almost all are proteins (other than the biogenic amines) and definitive evidence 


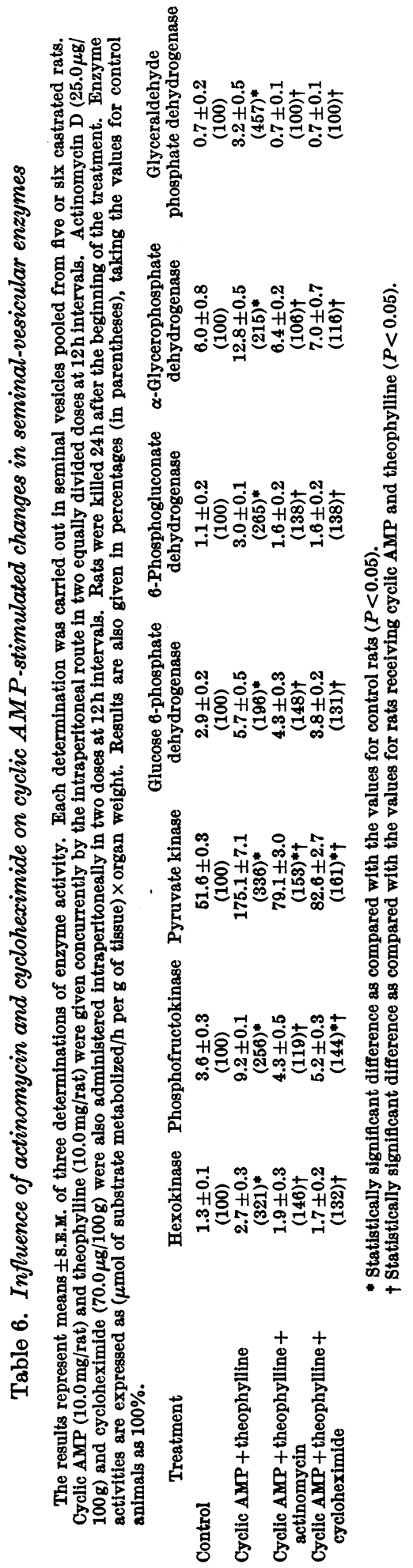

for the role of this cyclic nucleotide in the mechanism of action of sex steroidal hormones is still lacking (Robison, 1970). Several different approaches have been used for the study of the possible involvement of cyclic AMP in the action of a given hormone (Sutherland et al. 1969). The approach that involves an examination of the ability of exogenously administered cyclic AMP to reproduce physiological and biochemical effects of a given hormone is considered to be relatively difficult, since cyclic AMP penetrates cells poorly and in some cases, probably not at all (Robison, Butcher, Øye, Morgan \& Sutherland, 1965). However, cyclic AMP has been shown to mimic hormonal action in several tissues such as liver, adrenal cortex, toad bladder, frog skin, isolated fat-cells (Haynes, Koritz \& Peron, 1959; Bitensky \& Burnstein, 1965; Butcher et al. 1965; Orloff \& Handler, 1967), and more recently in the uterus (Singhal \& Lafreniere, 1970).

The present study demonstrates that cyclic AMP, when given concurrently with theophylline, is capable of mimicking the stimulatory action of testosterone on several important carbohydratemetabolizing enzymes in the prostate gland and seminal vesicles of castrated and immature rats. Although a dose of $2.5 \mathrm{mg}$ of cyclic AMP/rat was sufficient to produce statistically significant increases in most enzyme activities, relatively high doses $(10.0-20.0 \mathrm{mg} / \mathrm{rat})$ of this nucleotide were required to induce maximal stimulation of the prostatic and vesicular enzymes. Dibutyryl cyclic AMP produced greater increases in the activities of all prostatic and vesicular enzymes examined than those induced by the parent compound. Although acylated derivatives of cyclic AMP such as the dibutyryl analogue are generally more potent than the parent compound, evidence also exists for the divergent biological effects of cyclic AMP and dibutyryl cyclic AMP in fat-cells and HeLa cells (Hilz \& Tarnowski, 1970; Solomon, Brush \& Kitabchi, 1970). Concurrent treatment with actinomycin or cycloheximide effectively inhibited the cyclic AMP and theophylline-induced enhancement of all prostatic and vesicular enzymes, suggesting that the cyclic AMP-stimulated increases may represent enzyme synthesis de novo.

Singhal \& Lafreniere (1970) demonstrated that cyclic AMP produced oestradiol-like induction of phosphofructokinase activity in uteri of both ovariectomized and immature rats. The stimulation of the uterine enzyme by either cyclic AMP or its dibutyryl analogue was independent of adrenal function, and actinomycin and cycloheximide inhibited equally well the cyclic nucleotide-induced increases in uterine phosphofructokinase activity in ovariectomized and adrenalectomized-ovariectomized rats. Further, administration of theo- 


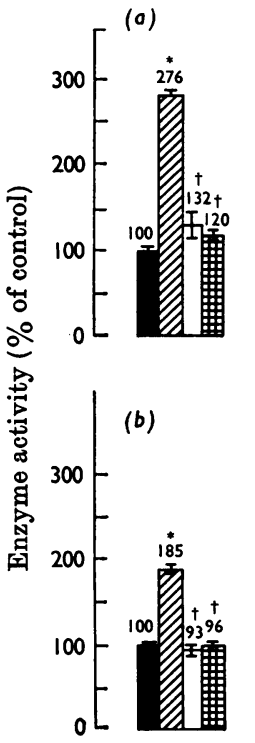

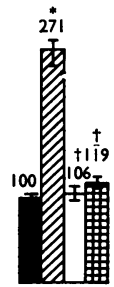
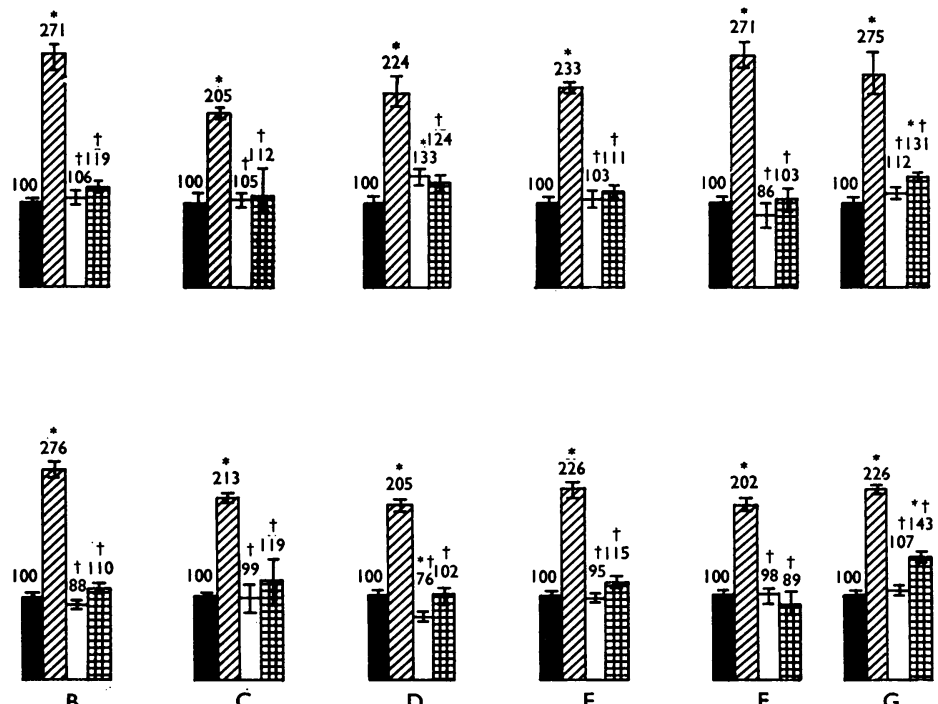

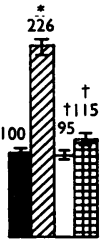

E

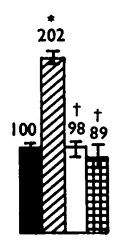

$\mathbf{F}$

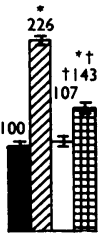

G

Fig. 6. Effect of cyclic AMP and theophylline on (a) prostatic and (b) vesicular enzymes in adrenalectomizedcastrated rats. Bars represent the means and s.w.M. of three values each obtained by pooling tissues from four rats. Cyclic AMP (10.0 mg/rat) and theophylline $(10.0 \mathrm{mg} / \mathrm{rat})$ were injected concurrently, by the intraperitoneal route in two equally divided doses at $12 \mathrm{~h}$ intervals. Actinomycin $\mathrm{D}(25.0 \mu \mathrm{g} / 100 \mathrm{~g})$ and cycloheximide $(70.0 \mu \mathrm{g} / 100 \mathrm{~g})$ were also given intraperitoneally, in two doses concurrently with cyclic AMP. A, Hexokinase; B, phosphofructokinase; C, pyruvate kinase; D, glucose 6-phosphate dehydrogenase; E, 6-phosphogluconate dehydrogenase; F, $\alpha$-glycerophosphate dehydrogenase; $G$, glyceraldehyde phosphate dehydrogenase. Results are given in percentages, taking the values for control rats as $100 \%$. E, Control; , cyclic AMP+theophylline; $\square$, cyclic AMP +theophylline+actinomycin; 曲, cyclic AMP +theophylline+cycloheximide. * Statistically significant difference when compared with the values for control rats $(P<0.05)$. $†$ Statistically significant difference when compared with the values for rats given cyclic AMP and theophylline $(P<0.05)$.

phylline potentiated the action of small doses of oestradiol-17 $\beta$ on uterine phosphofructokinase and other key glycolytic enzymes in ovariectomized rats, which provided additional support to the involvement of cyclic AMP in oestrogen action (Lafreniere \& Singhal, 1971). This paper shows that theophylline also was capable of potentiating the effects of a submaximal dose of testosterone on the activities of all those prostatic and vesicular enzymes that are increased by exogenous cyclic AMP. In addition, theophylline potentiated the ability of a small dose of testosterone to increase glycogen content of the prostate gland and seminal vesicles in castrated rats (R. L. Singhal, unpublished work). It is noteworthy that the lipolysis in fat-cells caused by catecholamines, glucagon and adrenocorticotrophic hormone (Butcher, Baird \& Sutherland, 1968a; Blecher, Merlino \& Ro'Ane, 1968; Hynie, Krishna \& Brodie, 1966; Halkerstan, Feinstein \& Hechter, 1966), the effects of vasopressin on the toad bladder (Orloff \& Handler, 1962), the cardiac inotropic responses to noradrenaline
Table 7. Effect of testosterone treatment on cyclic $A M P$ concentration in the prostate gland and seminal vesicles of castrated rats

The results represent means \pm s.c.M. of three determinations of cyclic AMP concentration in the prostate gland and seminal vesicles pooled from three or four rats. Rats were injected with testosterone propionate $(5.0 \mathrm{mg} /$ $100 \mathrm{~g}$ ) intramuscularly and killed after 8 and $24 \mathrm{~h}$. The results are also given in percentages (in parentheses), taking the values for control animals as $100 \%$.

\begin{tabular}{lcc}
\multirow{2}{*}{ Treatment } & Cyclic AMP (pmol/organ) \\
\cline { 2 - 3 } Control & $\begin{array}{c}\text { Prostate glands } \\
\text { S3.1 }\end{array}$ & Seminal vesicles \\
Testosterone (8h) & $(100)$ & $7.1 \pm 0.05$ \\
& $59.8 \pm 3.2$ & $(100)$ \\
Testosterone (24h) & $(140)^{*}$ & $9.9 \pm 0.01$ \\
& $61.9 \pm 3.4$ & $(140)^{*}$ \\
& $(145)^{*}$ & $(210)^{*}$
\end{tabular}

* Statistically significant difference as compared with the values for oontrol rats $(P<0.05)$. 

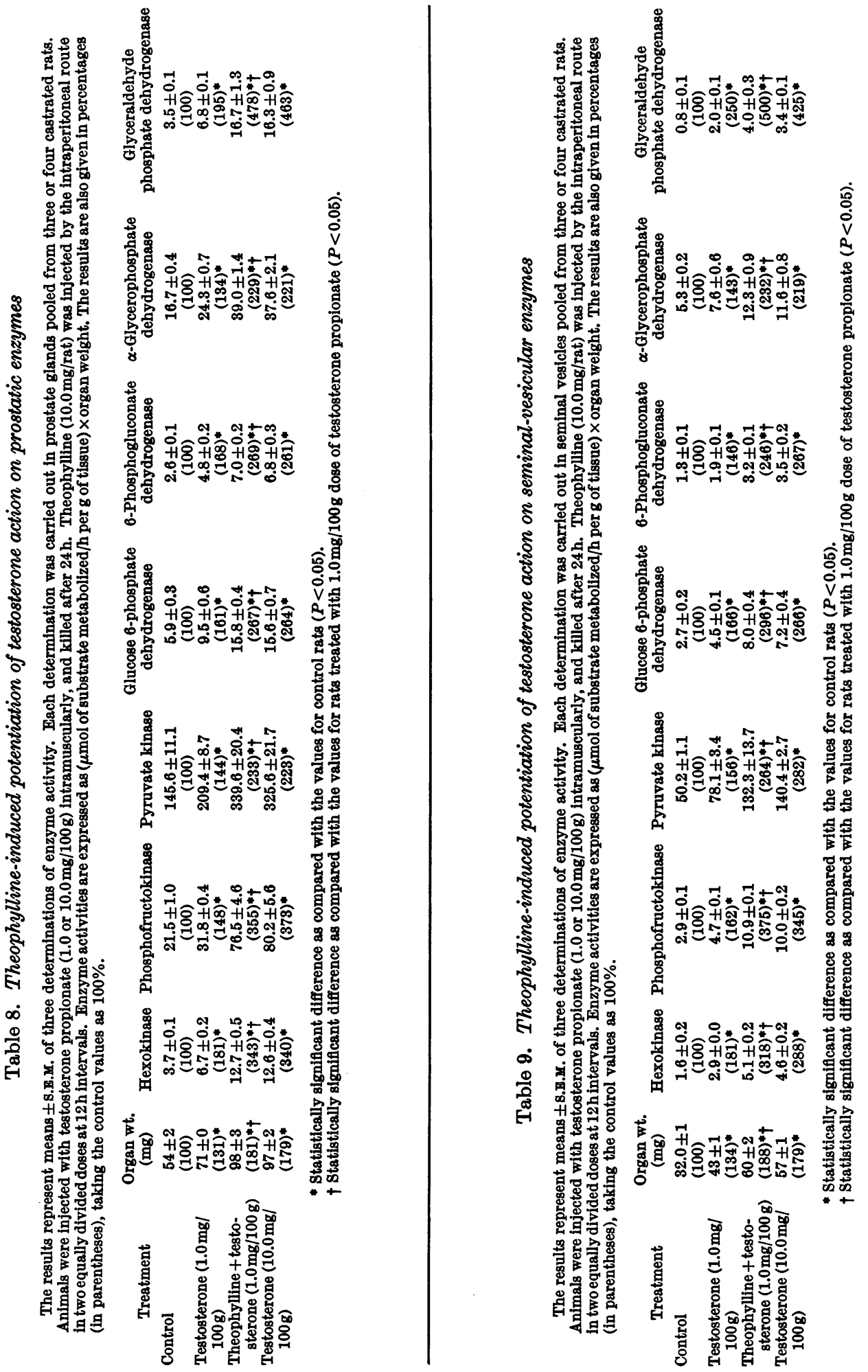
(Rall \& West, 1963) and the effects of isoproterenol on DNA synthesis in parotid glands (Malamud, 1969) have also been shown to be potentiated by methylxanthines.

Hechter et al. (1967) demonstrated that cyclic AMP increased uterine synthesis of RNA and protein and produced widespread stimulation of biosynthetic processes known to be influenced by the administration of oestrogens to ovariectomized animals in vivo. Since these oestrogen-like effects of cyclic AMP were shared by other compounds such as adenosine and guanosine monophosphate, it is possible that a set of specific nucleotides (not cyclic AMP alone) generated by oestradiol action may be responsible for propagating the known oestrogenic responses in the uterus. We have found that specificity exists for the stimulating action of cyclic AMP on various prostatic and vesicular enzymes, since adenosine as well as several related adenine nucleotides (5'-AMP; $2^{\prime}$ : $3^{\prime}$-AMP; $2^{\prime}$-AMP; $5^{\prime}$-AMP; 5'-ADP and $5^{\prime}$-ATP) failed to produce any appreciable change in any of the enzymes studied (R. L. Singhal, unpublished work). A certain degree of tissue specificity was also indicated, since neither the glycolytic or hexose monophosphate-shunt enzymes nor the activity of $\alpha$ glycerophosphate dehydrogenase was altered by cyclic AMP and theophylline in hepatic tissue (R. L. Singhal, unpublished work). It is noteworthy that the increase in the concentration of cyclic AMP by oestradiol-17 $\beta$ was also specific to uterus, since the hormone did not produce any change in cyclic AMP concentration of the diaphragm and mesometrial fat-pad, two tissues that do not respond to oestrogens (Szego \& Davis, 1967).

The present study constitutes, to the best of our knowledge, the first demonstration that cyclic AMP may be involved as an intracellular mediator in triggering the metabolic actions of androgens on the prostate gland and seminal vesicles. The ability of testosterone to increase the concentration of cyclic AMP in the prostate and seminal vesicles of castrated animals provides additional support for the involvement of this cyclic nucleotide in androgen action. Rosenfeld \& O'Malley (1970) found that the administration of testosterone propionate $(2.0 \mathrm{mg} / \mathrm{rat})$ to 6 -week-old hypophysectomized rats did not activate adenylate cyclase activity in the ventral prostate. The ventral prostate is least responsive to testosterone stimulation when compared with other lobes of the prostate gland (Price, 1963; Ofner, 1968). In addition, in hypophysectomized rats, the ventral prostate exhibits a greater degree of histological involution and loss in weight than in castrated animals (Price, 1963; Ofner, 1968). Since the uptake of testosterone by the ventral prostate is also decreased after hypophysectomy (Lawrence \& Landau, 1965), it is possible that the $2.0 \mathrm{mg}$ dose of the hormone used by Rosenfeld \& O'Malley (1970) may not have been adequate to cause measurable activation of adenylate cyclase in this tissue. The ability of exogenous cyclic AMP to mimic metabolic effects of testosterone, in conjunction with the observations that theophylline potentiates the action of a submaximal dose of this hormone and that administration of testosterone can increase cyclic AMP concentration in the prostate gland and seminal vesicles, substantiates the theory that this cyclic nucleotide is involved in the mechanism of action of androgenic steroids.

This investigation was supported by grants from the Medical Research Council of Canada, National Institutes of Health, U.S. Public Health Service (AM-14240), Eli Lilly and Co., Indianapolis, Ind., U.S.A. and the Upjohn Co., Kalamazoo, Mich., U.S.A. We are indebted to Professor G. M. Ling for his advice and many valuable discussions and to Professor J. Ashmore (Indiana University) for the initial gift of dibutyryl cyclic AMP. The competent technical help of Mrs Diane McNeil is gratefully acknowledged. R.L.S. is a Medical Research Scholar of the Medical Research Council of Canada and R.V. is a Colombo Plan post-doctoral fellow.

\section{REFERENCES}

Bitensky, M. W. \& Burnstein, S. R. (1965). Nature, Lond., 208, 1282.

Blecher, M., Merlino, N. S. \& Ro'Ane, J. T. (1968). J. biol. Chem. 243, 3973.

Butcher, R. W., Baird, C. E. \& Sutherland, E. W. (1968a). J. biol. Chem. 243, 1705.

Butcher, R. W., Ho, R. J., Meng, H. C. \& Sutherland, E. W. (1965). J. biol. Chem. 240, 4515.

Butcher, R. W., Robison, G. A., Hardman, J. C. \& Sutherland, E. W. (1968b). In Advances in Enzyme Regulation, vol. 6, p. 357. Ed. by Weber, G. Oxford: Pergamon Press Ltd.

Ennis, H. L. \& Lubin, M. (1964). Fedn Proc. Fedn Am. Socs exp. Biol. 23, 269.

Freedland, R. (1969). J. Nutr. 91, 489.

Halkerstan, I. D. K., Feinstein, M. \& Hechter, O. (1966). Proc. Soc. exp. Biol. Med. 122, 896.

Haynes, R. C., Koritz, S. B. \& Peron, F. G. (1959). J. biol. Chem. 234, 1421.

Hechter, O., Yoshinaga, K., Halkerstan, D. K. \& Birchall, K. (1967). Archs Biochem. Biophys. 122, 449.

Hilz, H. \& Tarnowski, W. (1970). Biochem. biophys. Res. Commun. 40, 973.

Hynie, S., Krishna, G. \& Brodie, B. B. (1966). J. Pharmac. exp. Ther. 153, 90.

Lafreniere, R. \& Singhal, R. L. (1971). Steroids, 17, 323.

Lawrence, A. M. \& Landau, R. L. (1965). Endocrinology, 77, 1119.

Malamud, D. (1969). Biochem. biophys. Res. Commun. 35, 754.

Ofner, P. (1968). Vitams Horm. 26, 237. 
Orloff, J. \& Handler, J. S. (1962). J. clin. Invest. 41, 702. Orloff, J. \& Handler, J. S. (1967). Am.J. Med.42, 757.

Price, D. (1963). Natn. Cancer Inst. Monog. no. 12, p. 1.

Rall, T. W. \& West, T. C. (1963). J. Pharmac. exp. Ther. 139, 269.

Reich, E., Franklin, R. M., Shatkin, A. J. \& Tatum, E. L. (1961). Science, N.Y., 134, 556.

Robison, G. A. (1970). J. Reprod. Fert. 10, 65.

Robison, G. A., Butcher, R. W., Øye, I., Morgan, H. E. \& Sutherland, E. W. (1965). Molec. Pharmac. 1, 168.

Rosenfeld, M. G. \& O'Malley, B. W. (1970). Science, N.Y., 168, 253.

Siegel, M. R. \& Sisler, H. D. (1964). Nature, Lond., 200, 675.

Singhal, R. L. \& Lafreniere, R. (1970). Endocrinology, 87, 1099.

Singhal, R. L. \& Ling, G. M. (1969). Can. J. Physiol. Pharmac. 47, 233.

Singhal, R. L., Robison, G. A. \& Parulekar, M. R. (1971). Proc. int. Union physiol. Sci., Munich, vol. 19 (in the Press).

Singhal, R. L. \& Valadares, J. R. E. (1967). Steroids, 9, 367.

Singhal, R. L. \& Valadares, J. R. E. (1968). Biochem. J. $110,703$.

Singhal, R. L. \& Valadares, J. R. E. (1970). Am. J. Physiol. 218, 321.

Singhal, R. L., Valadares, J. R. E. \& Ling, G. M. (1967). J. biol. Chem. 242, 2593.

Singhal, R. L., Valadares, J. R. E. \& Ling, G. M. (1969). Am. J. Physiol. 217, 793.
Singhal, R. L., Valadares, J. R. E. \& Schwark, W. S. (1970a). Biochem. Pharmac. 19, 2145.

Singhal, R. L., Vijayvargiya, R. \& Ling, G. M. (1970b). Science, N.Y., 168, 261.

Singhal, R. L., Vijayvargiya, R., Parulekar, M. R. \& Ling, G. M. (1970c). J. Cell Biol. 47, 193a.

Singhal, R. L., Wang, D. J. \& Iing, G. M. (1968). Proc. Can. Fedn biol. Soc. 11, 146.

Solomon, S. S., Brush, J. S. \& Kitabohi, A. E. (1970). Science, N.Y., 169, 387.

Sutherland, E. W., Hardman, J. G., Butcher, R. W. \& Broadus, A. E. (1969). In Progress in Endocrinology, p. 26. Ed. by Gual, C. Amsterdam: Excerpta Medica Foundation.

Sutherland, E. W. \& Robison, G. A. (1969). Diabetes, 18, 797.

Sutherland, E. W., Robison, G. A. \& Butcher, R. W. (1968). Circulation, 37, 279.

Szego, C. M. \& Davis, J. S. (1967). Proc. natn. Acad. Sci. U.S.A. 58, 1711.

Tamaoki, T. \& Mueller, G. C. (1962). Biochem. biophys. Res. Commun. 9, 451.

Valadares, J. R. E., Singhal, R. L. \& Parulekar, M. R. (1968). Science, N.Y., 159, 990.

Vijayvargiya, R., Schwark, W. S. \& Singhal, R. L. (1969). Can. J. Biochem. 47, 895.

Vijayvargiya, R. \& Singhal, R. L. (1970). Proc. Soc. exp. Biol. Med. 133, 670.

Williams-Ashman, H. G. (1965a). J. cell. comp. Physiol. 66, 111.

Williams-Ashman, H. G. (1965b). Cancer Res. 25, 1096. 